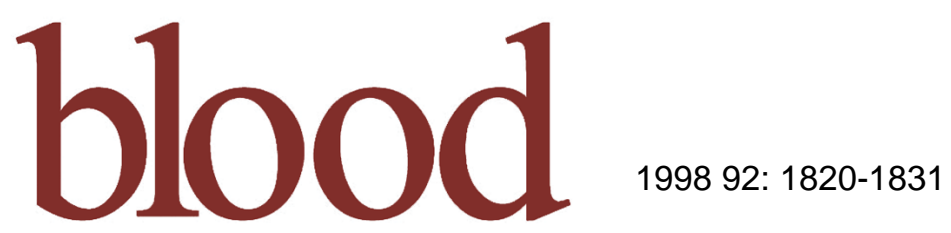

\title{
Comparative Analysis of Autografting in Chronic Myelogenous Leukemia: Effects of Priming Regimen and Marrow or Blood Origin of Stem Cells
}

Catherine M. Verfaillie, Ravi Bhatia, Michael Steinbuch, Todd DeFor, Betsy Hirsch, Jeffrey S. Miller, Daniel Weisdorf and Philip B. McGlave

Updated information and services can be found at:

http://bloodjournal.hematologylibrary.org/cgi/content/full/92/5/1820

Articles on similar topics may be found in the following Blood collections:

Transplantation (1539 articles)

Information about reproducing this article in parts or in its entirety may be found online at:

http://bloodjournal.hematologylibrary.org/misc/rights.dtl\#repub_requests

Information about ordering reprints may be found online at:

http://bloodjournal.hematologylibrary.org/misc/rights.dt|\#reprints

Information about subscriptions and ASH membership may be found online at:

http://bloodjournal.hematologylibrary.org/subscriptions/index.dtl

Blood (print ISSN 0006-4971, online ISSN 1528-0020), is published semimonthly by the American Society of Hematology, 1900 M St, NW, Suite 200, Washington DC 20036.

Copyright 2007 by The American Society of Hematology; all rights reserved.

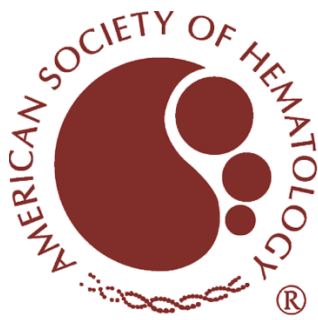




\title{
Comparative Analysis of Autografting in Chronic Myelogenous Leukemia: Effects of Priming Regimen and Marrow or Blood Origin of Stem Cells
}

\author{
By Catherine M. Verfaillie, Ravi Bhatia, Michael Steinbuch, Todd DeFor, Betsy Hirsch, \\ J effrey S. Miller, Daniel Weisdorf, and Philip B. McGlave
}

\begin{abstract}
The aims of this study were (1) to evaluate the effect of intermediate (cyclophosphamide alone) or intensive (mitoxantrone, cytosine arabinoside, cyclophosphamide) priming on the cytogenetic response in mobilized bone marrow (BM) or peripheral blood (PB) progenitors in patients with chronic myelogenous leukemia (CML), (2) to determine the incidence of cytogenetic remissions after mobilized progenitor transplantation in CML, and (3) to determine the effect of in vivo priming on the ability to select Philadelphia chromosomenegative (Ph-negative) CD34+HLA-DR- cells from mobilized BM or PB in quantities sufficient for transplantation. Between February 1994 and March 1997, 44 patients were enrolled in three sequential protocols. Although the duration of neutropenia after only cyclophosphamide mobilization was shorter, clinical morbidity for the intermediate and intensive priming protocols was similar. Cytogenetic responses in mobilized PB progenitors were similar after mobilization with either intermediate or intensive chemotherapy. The degree of $\mathrm{Ph}$ negativity in the mobilized product correlated with disease stage at the time of mobilization (early chronic phase [ECP] > late CP > accelerated phase).
\end{abstract}

C HRONIC MYELOGENOUS leukemia (CML) is a malignancy of the human hematopoietic stem cell. ${ }^{1}$ The disease is caused by the Philadelphia chromosome $(\mathrm{Ph})^{2}$ resulting from a translocation between the c-bcr gene located on chromosome 22 and the c-abl gene located on chromosome $9 .{ }^{3}$ The $\mathrm{p} 210^{\mathrm{BCR} / \mathrm{ABL}}$ oncoprotein is necessary and sufficient for malignant transformation. ${ }^{4} \mathrm{p} 210^{\mathrm{BCR} / \mathrm{ABL}}$ has increased tyrosine kinase activity compared with $\mathrm{p} 145^{\mathrm{ABL}} 5$ and binds abnormally to the actin-cytoskeleton ${ }^{6}$; these characteristics are thought to be responsible for inducing the malignant behavior of target cells.

CML is a disease that is most frequent during the fifth and sixth decade of life. ${ }^{7}$ CML is invariably lethal. After a chronic phase (CP) which lasts 3 to 4 years, the disease transforms into an accelerated phase and ultimate blast crisis. ${ }^{7}$ Although therapy with single-agent chemotherapeutic agents controls symptoms

From the Department of Medicine, Stem Cell Biology Program, Bone Marrow Transplantation Program, and Department of Laboratory Medicine at the University of Minnesota, Minneapolis, MN; and The City of Hope Medical Center, Duarte, CA.

Submitted November 4, 1997; accepted April 23, 1998.

C.M.V. is a Scholar of the Leukemia Society of America.

Supported in part by National Institutes of Health Grants PO1-CA65493 and PO1-CA-21737, the Leukemia Society of America Translational Research Grant 6377-97, and funds from the University of Minnesota Hospitals and Clinics.

Address reprint requests to Catherine M. Verfaillie, MD, Department of Medicine, Box 806 UMHC, 420 Delaware St SE, Minneapolis, MN 55455; e-mail:verfa001@maroon.tc.umn.edu.

The publication costs of this article were defrayed in part by page charge payment. This article must therefore be hereby marked "advertisement" in accordance with 18 U.S.C. section 1734 solely to indicate this fact.

(1) 1998 by The American Society of Hematology.

0006-4971/98/9205-0033\$3.00/0
Cytogenetic responses after transplantation with mobilized progenitors obtained after the different regimens were similar. The cytogenetic status of the graft predicted the cytogenetic status of marrow obtained 3 weeks after transplantation whereas cytogenetic responses 3, 6, and 12 months after transplantation correlated with the number of BCR/ABLnegative CD34 ${ }^{+} \mathrm{HLA}^{-D R^{-}}$cells, but not the number of Phnegative metaphases in the graft. In patients with ECP CML, mobilized PB collections yielded significantly more $\mathrm{CD}^{+} 4^{+} \mathrm{HLA}^{-\mathrm{DR}^{-}}$cells than from steady state or mobilized BM. CD34 ${ }^{+}$HLA-DR $^{-}$cells were $\mathrm{Ph}$ negative and polyclonal (X-chromosome inactivation) in the majority of ECP CML patients, before and after mobilization and irrespective of the mobilization regimen. Because infusion of large numbers of Ph-negative CD34+ ${ }^{+}$HLA-DR $^{-}$cells predicted superior outcome after transplantation, approaches in which CD34+ HLA$D^{-}$cells are selected from mobilized PB may result in longer lasting and clinically significant cytogenetic responses after transplantation.

(1) 1998 by The American Society of Hematology.

during the $\mathrm{CP},{ }^{7}$ disease outcome is not affected. Therapy with interferon- $\alpha$ (IFN- $\alpha)$, either alone ${ }^{8-11}$ or in combination with cytosine arabinoside ${ }^{12}$ can induce hematologic remissions in $>80 \%$ of CP patients. In addition, $10 \%$ to $25 \%$ of patients obtain a major cytogenetic response, which is associated with a superior survival. However, acquisition of a hematologic response without major cytogenetic response does not significantly affect survival. ${ }^{8-11}$ Ablative chemotherapy with or without irradiation therapy followed by infusion of normal stem cells obtained from a closely matched related or unrelated donor results in 5-year disease-free survival of $30 \%$ to $80 \% .^{13,14}$ Success of transplantation is dependent on the degree of donor match, age of the patient, and the disease stage and duration at the time of transplantation. ${ }^{15}$ However, a large proportion of patients are ineligible for allogeneic transplantation due to age or lack of a suitably matched donor.

Several lines of evidence suggest that benign Ph-negative stem cells may coexist with the Ph-positive clone in patients with CML. At diagnosis, some patients have evidence of Ph-negative hematopoiesis on routine cytogenetic studies of the bone marrow (BM). ${ }^{16,17}$ Treatment with IFN- $\alpha,{ }^{8-13}$ busulphan, ${ }^{18}$ or intensive chemotherapy ${ }^{19}$ can result in the reestablishment of Ph-negative hematopoiesis. Culture of CML BM or peripheral blood (PB) in long-term culture reveals presence of normal Ph-negative primitive progenitors. ${ }^{20,21} \mathrm{We}$ and others have shown that $\mathrm{CD}_{3} 4^{+} \mathrm{HLA}-\mathrm{DR}^{-}$cells present in steady-state BM of early $\mathrm{CP}$ (ECP) CML patients are highly enriched in Ph-negative, BCR/ABL mRNA-negative, and polyclonal primitive long-term culture initiating cells. ${ }^{22-25}$ This has led to the hypothesis that autologous transplantation of PB or BM cells may restore Ph-negative hematopoiesis. Transplantation of autologous PB or BM cultured in long-term culture ${ }^{20,21}$ or exposed short term to IFN- $\gamma,{ }^{26}$ mafosfamide, ${ }^{27}$ or anti-myb antisense oligonucleotides ${ }^{28}$ has resulted in at least temporary 
restoration of Ph-negative hematopoiesis. More recently, several studies have indicated that transplantation of PB cells obtained after in vivo mobilization with chemotherapy and cytokines may also result in the reestablishment of $\mathrm{Ph}$-negative hematopoiesis. ${ }^{19,29-35}$

In this study we sought to compare the effect of priming with intermediate or high-dose chemotherapy and granulocyte colonystimulating factor (G-CSF) or granulocyte-macrophage colonystimulating factor (GM-CSF) on the mobilization of $\mathrm{Ph}$ negative progenitors in $\mathrm{BM}$ and $\mathrm{PB}$. We correlated the early course of patients transplanted with either BM or PB cells obtained after in vivo chemotherapy priming with patient characteristics, type of mobilizing chemotherapy, and graft characteristics. We also examined the effect of priming on the

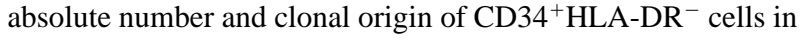
$\mathrm{PB}$ and $\mathrm{BM}$.

\section{MATERIALS AND METHODS}

\section{Patients}

Between February 1994 and March 1997, 44 patients with CML were enrolled on three sequential autologous transplantation protocols at the University of Minnesota after informed consent was obtained using guidelines approved by the Committee on the Use of Human Subjects for Research at the University of Minnesota. Patient characteristics at the time of transplantation including age, gender, disease phase, prior therapy, BM cytogenetics, BCR/ABL status, and white blood cell (WBC) count are summarized in Table 1. Patients were classified using the criteria from the National Marrow Donor Program (NMDP) characterizing $\mathrm{CP}$ and accelerated phase disease. Chronic phase is defined as no significant symptoms after treatment, no features of accelerated phase or blast crisis, and no cytogenetic changes other than the $\mathrm{Ph}$ chromosome. Accelerated phase is defined as a rapid doubling of the WBC count, $>10 \%$ blasts in blood or marrow, $>20 \%$ basophils and eosinophils in blood or marrow, anemia, thrombocytopenia, thrombocytosis, additional cytogenetic abnormalities, splenomegaly not responsive to therapy, and severe myelofibrosis. ${ }^{36}$

\section{Mobilization Regimens}

Between February 1994 and September 1995, 17 patients were mobilized with a single dose of cyclophosphamide $\left(4 \mathrm{~g} / \mathrm{m}^{2}\right)$ and GM-CSF $\left(250 \mu \mathrm{g} / \mathrm{m}^{2}\right)$ from day 4 after cyclophosphamide administration until the end of the PB progenitor cell (PBPC) collections (protocol $\mathrm{CY} / \mathrm{GM} / \mathrm{BM}$ ). When the absolute neutrophil count (ANC) was 500 to $1,000 / \mu \mathrm{L}, \mathrm{a} \mathrm{BM}$ harvest $(1.5 \mathrm{~L}$ ) followed by three (range, three to six) PBPC products were obtained. BM and PBPC cells were cryopreserved without further manipulation and the BM was used as the graft.

From September 1995 to September 1996, 18 patients received priming cyclophosphamide ( $4 \mathrm{~g} / \mathrm{m}^{2}$, day 1$)$, mitoxantrone $\left(4 \mathrm{mg} / \mathrm{m}^{2}\right.$, days 1 and 2), and cytosine arabinoside $\left(1 \mathrm{~g} / \mathrm{m}^{2}\right.$ twice daily, days 1 and 2) followed by G-CSF $(5 \mu \mathrm{g} / \mathrm{kg})$ from day 4 until the end of PBPC collections as mobilization (protocol MAC/G/PB). Patients underwent a BM harvest $\left(2 \times 10^{8}\right.$ mononuclear cells $\left.[\mathrm{MNC}] / \mathrm{kg}\right)$ before initiation of the mobilization regimen (cryopreserved as back-up BM stem cells). Once the ANC reached 500 to $1,000 / \mu \mathrm{L}$, PBPC containing a minimum of $2 \times 10^{6} \mathrm{CD}^{+} 4^{+}$cells $/ \mathrm{kg}$ were collected and cryopreserved unmanipulated as graft (median number of collections, 5 ; range, 2 to 10). During the same period patients underwent a diagnostic BM aspirate.

Table 1. Patient Characteristics

\begin{tabular}{|c|c|c|c|}
\hline Patient Characteristic & $\begin{array}{l}\text { Cyclophosphamide GM-CSF } \\
\text { BM Transplant CY/GM/BM }\end{array}$ & $\begin{array}{c}\text { Cyclophosphamide, } \\
\text { ARA-C, and Mitoxantrone G-CSF } \\
\text { PBPC Transplant MAC/G/PB }\end{array}$ & $\begin{array}{l}\text { Cyclophosphamide G-CSF } \\
\text { PBPC Transplant CY/G/PB }\end{array}$ \\
\hline Total & $17^{*}$ & $18+$ & $9 \neq$ \\
\hline Age (range; median) & $29-60 ; 47$ & $35-62 ; 50$ & $36-62 ; 57$ \\
\hline \multicolumn{4}{|l|}{ Sex } \\
\hline Male & 11 & 9 & 3 \\
\hline Female & 6 & 9 & 6 \\
\hline \multicolumn{4}{|l|}{ Disease stage§ } \\
\hline ECP & 5 & 7 & 3 \\
\hline LCP & 8 & 6 & 4 \\
\hline Accelerated phase & 4 & 5 & 2 \\
\hline \multicolumn{4}{|l|}{ Prior therapy } \\
\hline Hydroxyurea & 14 & 12 & 6 \\
\hline IFN- $\alpha$ & 1 & 0 & 1 \\
\hline Hydroxyurea/IFN- $\alpha$ & 1 & 4 & 1 \\
\hline Multiple\| & 1 & 2 & 1 \\
\hline \multicolumn{4}{|l|}{ Ph positivet† } \\
\hline $100 \%$ & 15 & 11 & 8 \\
\hline$<100 \%$ & 29 & $6 \#$ & $1 * *$ \\
\hline Negative $\left(\mathrm{BCR} / \mathrm{ABL}^{+}\right)$ & 0 & 1 & 0 \\
\hline WBC at time of mobilization (range; median) & $2.9-84 ; 7.7$ & 2.4-27.2; 9.8 & $2.6-36.1 ; 4.75$ \\
\hline
\end{tabular}

*Two patients not transplanted: one patient insufficient progenitors collected, one patient developed blast crisis immediately after mobilization. †Four patients not transplanted: three patients insufficient progenitors, one patient died from pulmonary infection after mobilization.

¥Three patients not transplanted: insufficient CD34+ cells.

§For definition, see Materials and Methods.

\|One patient IFN- $\alpha$, hydroxyurea, and busulfan; two patients splenic irradiation and hydroxyurea.

ITwo ECP patients: $35 \%$ and $85 \%$ Ph-positive metaphases in pretransplantation BM.

\#Four ECP patients: $65 \%, 70 \%, 90 \%$, and 95\% Ph-positive metaphases in pretransplantation BM; two patients previously treated for 2.5 and 3 years with IFN- $\alpha$ with clonal evolution: (1) 35\% 46XX t(9,22); 10\% 45XX t(9,22) $\operatorname{der}(7)-12$; (2) 15\% 46XY t(9,22); 75\% 46XY t99,22), add (19).

** One ECP CML patient on IFN- $\alpha, 65 \%$ Ph positive, no clonal evolution.

t†ln most instances, these results are from analysis of a minimum of $20 \mathrm{BM}$ metaphases. 
From September 1996 to April 1997, an additional 9 patients received cyclophosphamide $\left(4 \mathrm{~g} / \mathrm{m}^{2}\right.$, day 1$)$ and G-CSF $(5 \mu \mathrm{g} / \mathrm{kg})$ from day 4 until the end of PBPC collections (protocol CY/G/PB). When the ANC reached 500 to $1,000 / \mu \mathrm{L}, \mathrm{PBPC}$ containing a minimum of $2 \times 10^{6}$ $\mathrm{CD}_{3} 4^{+}$cells $/ \mathrm{kg}$ PBPC (median number of collections, 4 ; range, 3 to 5 ) were collected and cryopreserved unmanipulated as graft.

The mobilizing chemotherapy was administered on the Inpatient Bone Marrow Transplantation (BMT) Unit at the University of Minnesota. After the mobilization chemotherapy, patients were discharged on prophylactic antibiotics (penicillin, fluconazole, and ciprofloxacin). They were seen daily in the Outpatient BMT Clinic where PB counts were followed and patients evaluated for infectious complications. When indicated, platelet and red blood cell (RBC) transfusions were administered and patients received intravenous antibiotics for febrile complications either as inpatients or outpatients, as needed.

\section{Transplantation}

All patients were myeloablated with cyclophosphamide $(60 \mathrm{mg} / \mathrm{kg}$, days -7 and -6$)$ and fractionated TBI (165 cGy twice daily; total dose, $1,320 \mathrm{cGy}$ on days $-4,-3,-2$, and -1 ) on the Inpatient BMT Unit at the University of Minnesota. Between February 1995 and January 1996, patients remained hospitalized until the ANC was $500 / \mu \mathrm{L}$ for 3 consecutive days. After January 1996, patients were discharged from the hospital whenever possible on day +1 after transplantation on prophylactic antibiotics. They were followed daily in the Outpatient BMT Clinic and readmitted to the Inpatient BMT Unit when febrile. All patients were eligible for additional supportive care study protocols including, but not limited to, those related to prophylaxis and treatment of infection, blood product support, mucositis, and/or nutritional support. After transplantation, patients received either GM-CSF $\left(250 \mu \mathrm{g} / \mathrm{m}^{2}\right.$, protocol $\mathrm{CY} / \mathrm{GM} / \mathrm{BM}$ ) or $\mathrm{G}-\mathrm{CSF}(5 \mu \mathrm{g} / \mathrm{kg}$; protocols $\mathrm{MAC} / \mathrm{G} / \mathrm{PB}$ and $\mathrm{CY} / \mathrm{G} / \mathrm{PB}$ ) until the $\mathrm{ANC}$ was $>2,500 / \mu \mathrm{L}$ for 3 consecutive days.

\section{Posttransplantation Immunotherapy}

IFN- $\alpha$ was administered once the ANC was $>1,000 / \mu \mathrm{L}$ for 3 days without cytokine support, platelets were $>80,000 / \mu \mathrm{L}$, and patients were $\mathrm{RBC}$ transfusion independent. The IFN dose was $0.1 \times 10^{6} \mathrm{U} / \mathrm{m}^{2}$ daily subcutaneous $(\mathrm{sc}) \times 1$ week, $0.25 \times 10^{6} \mathrm{U} / \mathrm{m}^{2}$ daily sc $\times 1$ week, $0.5 \times$ $10^{6} \mathrm{U} / \mathrm{m}^{2}$ daily sc $\times 1$ week, then escalated by $0.5 \mathrm{MU} / \mathrm{m}^{2}$ every 2 weeks to maximum tolerated dose.

\section{Posttransplantation Follow- $U p$}

Physical examination, analysis of routine chemistry, and PB studies were performed at 3 weeks and 3, 6, 9, and 12 months after transplantation and annually thereafter during scheduled outpatient visits to the BMT Clinic. BM samples were examined for morphological signs of relapse and for the presence of the $\mathrm{Ph}$ chromosome and the BCR/ABL mRNA by reverse transcription polymerase chain reaction (RT-PCR).

\section{In Vitro Studies}

We obtained a PB and BM sample before mobilization, a BM sample when the WBC count was 700 to $1,000 / \mu \mathrm{L}$ during the recovery phase after mobilization (CY/GM/BM and $\mathrm{MAC} / \mathrm{G} / \mathrm{PB})$, and a sample from each PBPC collection (CY/GM/BM, MAC/G/PB, and CY/G/PB). Each sample was examined for the presence of the $\mathrm{Ph}$ chromosome, the number of colony-forming cells (CFC) and long-term culture initiating cells (LTC-IC) present, and the number and clonal origin of CD34 ${ }^{+} \mathrm{HLA}-$ $\mathrm{DR}^{-}$cells.

Cell selection. $\mathrm{PB}$ and $\mathrm{BM} \mathrm{MNC}$ were isolated by Ficoll-Hypaque (Sigma Chemical Co, St Louis, MO) density gradient separation (specific gravity, 1.077) for 30 minutes at $37^{\circ} \mathrm{C}$ and $400 g$. A CD34enriched population was obtained from $\mathrm{PB}$ MNC and BM MNC using Ceprate avidin-biotin immunoadsorption columns (CellPro Inc, Bothell, WA) or the MiniMACS selection system (Amgen, Thousand Oaks,
CA). CD34-enriched cells were labeled with phycoerythrin (PE)conjugated mouse anti-CD34 antibodies and fluorescein isothiocyanate (FITC)-conjugated mouse anti-HLA-DR antibodies $\left(1 \mathrm{mg} / 10^{6}\right.$ cells $)$ (Becton Dickinson, San Jose, CA), incubated for 30 minutes on ice, and then washed with cold phosphate-buffered saline. Cells were selected on a FACStar-Plus laser flow cytometry system equipped with a CONSORT 32 computer (Becton Dickinson) for low forward and side scatter properties and expression of CD34 and HLA-DR antigens using mouse IgG1-PE and IgG2-FITC antibodies as control.22,23

Methylcellulose progenitor culture. As described, $2 \times 10^{5} \mathrm{BM}$

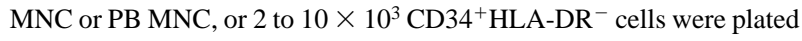
in methylcellulose containing Iscove's modified Dulbecco's medium (IMDM; GIBCO Laboratories, Grand Island, NY) supplemented with $30 \%$ fetal calf serum (FCS; Hyclone,Logan, UT), 3 IU erythropoietin (Epoietin; Amgen), and 10\% supernatant of the carcinoma cell line 5637. Cultures were incubated in a humidified atmosphere at $37^{\circ} \mathrm{C}$ and $5 \% \mathrm{CO}_{2}$. The cultures were assessed at days 14 to 18 for the presence of burst-forming unit-erythroid, colony-forming unit-granulocyte-macrophage, and mixed colony-forming unit as previously described. ${ }^{37}$

Long-term cultures. PB MNC or BM MNC $\left(1 \times 10^{6}\right)$ or CD34 ${ }^{+}$HLA-DR $^{-}$cells $\left(2\right.$ to $\left.10 \times 10^{3}\right)$ were plated in contact with confluent, irradiated M2-10B4 stromal layers (generous gift from Dr C. Eaves, Vancouver, British Columbia, Canada), subcultured in 24-well plates in complete LTC medium (IMDM; GIBCO) with $12.5 \%$ FCS, $12.5 \%$ horse serum (Terry Fox Laboratories, Vancouver, Canada), 2 $\mathrm{mmol} / \mathrm{L}$ glutamine (GIBCO), $100 \mathrm{U} / \mathrm{mL}$ penicillin, $100 \mathrm{U} / \mathrm{mL}$ streptomycin (GIBCO), and $10^{-6} \mathrm{~mol} / \mathrm{L}$ hydrocortisone. Cultures were maintained for 5 weeks in LTC medium in a humidified atmosphere at $37^{\circ} \mathrm{C}$ and $5 \% \mathrm{CO}_{2}$ as described. ${ }^{38}$ After 5 weeks, adherent and nonadherent cells were recovered by short-term trypsinization and replated in methylcellulose culture for 14 to 18 days.

\section{Cytogenetics}

$\mathrm{BM}$ or PB MNC were cultured overnight and subjected to a 1.5-hour colcemid incubation followed by lysis with hypotonic potassium chloride and fixation in acid/alcohol as previously described. Metaphases were analyzed after QFQ or GTG banding. ${ }^{39}$

\section{PCR Amplification of BCR/ABL $m R N A$}

Freshly obtained PB- or BM-derived MNC, CD34 ${ }^{+}$cells, or sorted

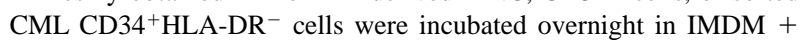
$20 \% \mathrm{FCS}$ at $37^{\circ} \mathrm{C}$ in a fully humidified $\mathrm{CO}_{2}$ incubator, and flash frozen at $-70^{\circ} \mathrm{C}$. RT-PCR to amplify BCR/ABL mRNA and the $\beta$-actin mRNA as mRNA control were performed as previously described. ${ }^{22,23,40}$

\section{Statistics}

Spearman's rank order correlation was used to measure the association between continuous variables in this study. In addition, the association between cell dose and time to engraftment was evaluated in a Cox regression analysis to account for two censored patients that died before being evaluable for engraftment. Estimates of survival and time to engraftment were calculated by Kaplan Meier estimation. Univariate comparisons of survival were completed with $95 \%$ confidence intervals (CIs) and the log-rank statistic. In comparing continuous variables between independent groups and matched groups, the paired and unpaired $t$-tests were used, respectively.

\section{RESULTS}

\section{Transplantations}

From February 1995 until April 1997, 44 consecutive patients with CML that presented to the University of Minnesota for autologous transplantation were enrolled in three sequential autologous transplantation protocols. Patient characteristics are 
summarized in Table 1. There were no significant differences between the three groups for the following parameters: gender, disease stage, cytogenetics at time of mobilization, or WBC count at time of mobilization. Sixteen patients were in ECP, which was defined as diagnosed less than 12 months before transplantation. Fifteen patients were in late CP (LCP), defined as diagnosed more than 1 year before transplantation but with no clinical or cytogenetic evidence of accelerated phase disease. Thirteen patients had accelerated phase disease, defined based on clinical criteria (thrombocytosis, cytopenias, splenomegaly, blast and basophil percentage, myelofibrosis, or clonal evolution). Because results for patients in LCP and with accelerated phase disease were not different, comparisons are reported between patients with ECP disease and patients with either LCP or accelerated disease combined (advanced phase [AP CML]).

After priming, the WBC count reached 700 to 1,000 at a median of 15,18 , and 13 days for protocols CY/GM/BM, $\mathrm{MAC} / \mathrm{G} / \mathrm{PB}$, and CY/G/PB respectively (Table 2). During the neutropenic phase after chemotherapy, three, two, and one patients enrolled on the three sequential protocols were hospitalized because of infectious complications. Two patients in protocol $\mathrm{CY} / \mathrm{GM} / \mathrm{BM}$, four patients in protocol $\mathrm{MAC} / \mathrm{G} / \mathrm{PB}$, and three patients in protocol $\mathrm{CY} / \mathrm{G} / \mathrm{PB}$ did not proceed to transplantation. Eight (1, 4, and 3) patients had insufficient $\mathrm{CD} 4^{+}$cells available for transplantation. These eight patients all had advanced-stage disease. One patient in protocol CY/ GM/BM developed blast crisis immediately after mobilization and one patient in protocol MAC/G/PB died before transplantation because of septic shock and diffuse lung damage. One additional patient enrolled in protocol MAC/G/PB developed pulmonary aspergillosis, requiring amphotericin-B therapy for 3 months before transplantation.

Fifteen (CY/GM/BM) (93.7\%), 14 (MAC/G/PB) (78\%), and $6(\mathrm{CY} / \mathrm{G} / \mathrm{PB})(66 \%)$ patients proceeded to transplantation. Patients received either autologous mobilized BM cells and GM-CSF after transplantation (CY/GM/BM) or autologous mobilized PBPC and G-CSF after transplantation (MAC/G/PB and $\mathrm{CY} / \mathrm{G} / \mathrm{PB})$. WBC $(P<.01)$, RBC $(P=.03)$, and platelet $(P=.01)$ engraftment was faster for patients receiving PBPC

Table 2. Transplantations: Clinical Data

\begin{tabular}{lccc}
\hline Characteristic & CY/GM/BM & MAC/G/PB & CY/G/PB \\
\hline $\begin{array}{l}\text { Mobilization* } \\
\text { Time to WBC }\end{array}$ & & & \\
$>700-1,000$ & $3-19 ; 15$ & $13-35 ; 18$ & $9-19 ; 16$ \\
CD34 ${ }^{+} \times 10^{6}$ cells $/ \mathrm{kg}$ & Not done & $2.1-114 ; 5.8$ & $1.5-7 ; 3.8$ \\
CFC $\left(\times 10^{4}\right) / \mathrm{kg}$ & $2.3-145 ; 6.7$ & $2.7-161 ; 38$ & $12-85 ; 61$ \\
LTC-IC $\left(\times 10^{3}\right) / \mathrm{kg}$ & $0.35-12 ; 5.4$ & $0.5-21 ; 3.2$ & $1-10 ; 6$
\end{tabular}

Transplantation

$\begin{array}{lcrr}\text { Time to engraftment* } & & & \\ \text { WBC } & 9-33 ; 13 & 9-18 ; 11 & 2-11 ; 10 \\ \text { Platelet } & 12->100 ; 37 & 15-49 ; 21 & 15-21 ; 19 \\ \text { RBC } & 22->100 ; 41 & 16-51 ; 30 & 25-46 ; 29\end{array}$

Survivalt

1-year survival $\quad 80 \%(60 \%-100 \%) \quad 86 \%(68 \%-100 \%) \quad$ NA

Abbreviation: NA, not applicable.

*Results are shown as range; median.

tResults are actuarial survival at 1 year $(95 \% \mathrm{Cl})$. cells (MAC/G/PB and CY/G/PB) than for patients receiving $\mathrm{BM}$ progenitors (CY/GM/BM) (Table 2).

Median follow-up after transplantation for patients on $\mathrm{CY} /$ $\mathrm{GM} / \mathrm{BM}$ is 27 months (range, 12 to 35 months). Five patients (33\%) died 65, 127, 238, 408, and 710 days after transplantation, respectively: one because of nonengraftment and four in blast crisis. The 1-year actuarial survival is $80 \%$ (95\% CI, $60 \%$ to $100 \%$ ). Median follow-up after transplantation for patients on MAC/G/PB is 12 months (range, 8 to 17 ). Four patients (28.5\%) died 32, 220, 461, and 560 days after transplantation, respectively: one because of infection and three in blast crisis. The 1-year actuarial survival of $86 \%$ (95\% CI, $68 \%$ to $100 \%)$ is not significantly different from that observed after transplantation on protocol CY/GM/BM. Median follow-up for patients on $\mathrm{CY} / \mathrm{G} / \mathrm{PB}$ is less than 6 months. One patient died in blast crisis (day 117) and one died because of gram-negative sepsis and acute lung injury occurring after engraftment (day 32).

One-year survival for ECP patients on the three protocols combined was $100 \%$ and 2-year survival was 53\% (95\% CI, $13 \%$ to $93 \%$ ) ( Fig 1A). One-year survival for AP patients was $62 \%(95 \% \mathrm{CI}, 40 \%$ to $84 \%)$ and 2-year survival was $52 \%(95 \%$ CI, 26\% to $78 \%$ ) (Fig 1A). When compared with a historical cohort of 43 patients who underwent autologous transplantation at the University of Minnesota using IFN- $\gamma$-purged BM, ${ }^{26} 1$ and 2-year survivals were similar ( $P=$ not significant) (Fig 1B).

Of the seven patients that did not undergo an autograft because of poor mobilization, two patients underwent an unrelated donor transplantation. One patient died from toxicity related to the transplantation procedure. The second patient is alive $2+$ months after transplantation. The other five patients did not receive further intensive therapy and were maintained on hydroxyurea. Three of the five patients remain in CP 1 to 2.5 years after mobilization. One of the five patients has accelerated phase disease and one patient is requiring intermittent G-CSF to support low neutrophil counts.

After transplantation patients were treated with increasing doses of IFN- $\alpha$ once the ANC was $>1,000 / \mu \mathrm{L}$ for 3 days without cytokine support, platelets were $>80,000 / \mu \mathrm{L}$, and patients were RBC transfusion independent. Twenty-four patients were eligible for IFN- $\alpha$ therapy and had been followed for more than 1 year after transplantation at the time of evaluation (1-year cytogenetics chosen to evaluate the possible effect of IFN- $\alpha$ on cytogenetics after transplantation). The IFN- $\alpha$ dose was always escalated to the maximally tolerated dose. Mainly because of hematopoietic toxicity (thrombocytopenia and/or neutropenia), dose escalation was not always possible. Patients received a maximum mean dose of IFN- $\alpha$ of $1.57 \pm 0.28 \times 10^{6}$ $\mathrm{U} / \mathrm{m}^{2} / \mathrm{d}$ (range, 0 to $5.5 \times 10^{6} \mathrm{U} / \mathrm{m}^{2} / \mathrm{d}$ ). No correlation between cytogenetics at 1 year and the dose of IFN- $\alpha$ was observed for either ECP or AP CML patients $\left(r^{2}=.139\right.$ for ECP CML and $r^{2}=.031$ for AP CML).

\section{Composition of the Graft}

$\mathrm{BM}$ and $\mathrm{PB}$ samples obtained before mobilization and at the time the ANC reached 500 to 1,000 after mobilization were evaluated for the number of CD $34^{+}$cells, CFC, and LTC-IC, as well as for the presence of Ph-positive metaphases. For ECP CML patients, the number of $\mathrm{CD} 34^{+}$cells, CFC, and LTC-IC in $\mathrm{BM}$ obtained during recovery after mobilization was signifi- 

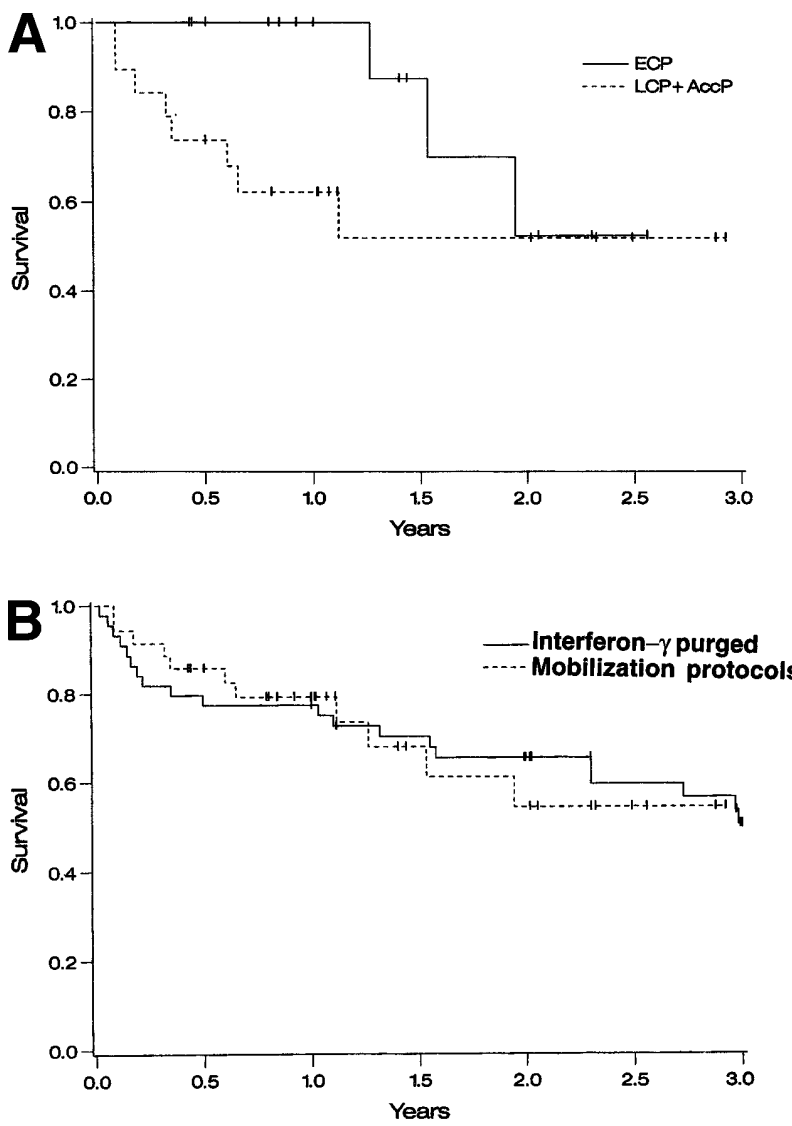

Fig 1. Survival of autografted CML patients - Cox regression analysis of survival. (A) Comparison between patients treated on protocols CY/GM/BM, MAC/G/PB, or CY/G/PB based on disease stage: ECP CML (diagnosed $<1$ year before transplantation and in CP), LCP CML (diagnosed $>1$ year before transplantation and in CP), and AP CML (diagnosed $>1$ year before transplantation and in CP or accelerated phase). (B) Comparison between patients transplanted at the University of Minnesota with IFN- $\gamma$-purged autologous marrow (1988 to 1994) and patients transplanted using primed BM or PB cells in protocols CY/GM/BM, MAC/G/PB, or CY/G/PB.

cantly lower than in steady-state BM or in the three to eight combined PBPC collections, and this was irrespective of the type of mobilization regimen $(P<.05)$ (data not shown). In contrast, differences were less significant for patients with AP CML.

Cytogenetic analysis of steady-state BM, and BM or PB obtained after mobilization is summarized in Figs 2 and 3. In most instances a minimum of 20 metaphases were analyzed. Before mobilization, BM of $18.6 \%$ of patients was partially $\mathrm{Ph}$ negative. Three patients treated to partial $\mathrm{Ph}$ negativity with IFN- $\alpha$ had accelerated features defined as additional chromosomal abnormalities in a fraction or all of the persisting $\mathrm{Ph}$-positive population. In addition, four patients that were $100 \% \mathrm{Ph}$ positive also had signs of clonal evolution. When cytogenetics of the individual PBPC collections were compared, no significant change in the degree of $\mathrm{Ph}$ positivity between the first and last collection was observed (Fig 3). For the three sequential protocols, mobilization resulted in a major cytogenetic response in PB progenitors of $20 \%$ (CY/GM/BM),
$71 \%$ (MAC/G/PB), and 0\% (CY/G/PB); a minor cytogenetic response in $80 \%, 29 \%$, and $100 \%$; and no cytogenetic response in $0 \%, 0 \%$, and $0 \%$ of ECP CML patients (Fig 2). For AP patients, a major cytogenetic response was seen in $\mathrm{PB}$ progenitors of $25 \%, 17 \%$, and $0 \%$ of patients; a minor cytogenetic response in $22 \%, 1 \%$, and $0 \%$ of patients; and no cytogenetic response in $50 \%, 66 \%$, and $100 \%$ of patients on the three sequential protocols. Cytogenetics were also available for BM MNC obtained at the time of hematopoietic recovery from patients on protocols $\mathrm{CY} / \mathrm{GM} / \mathrm{BM}$ and $\mathrm{MAC} / \mathrm{G} / \mathrm{PB}$. The degree of $\mathrm{Ph}$ positivity in $\mathrm{BM}$ and $\mathrm{PB} \mathrm{MNC}$ was similar $\left(r^{2}=.73 ; P<\right.$ .0001).

\section{Effect of Graft Composition on Engraftment}

Patients transplanted with mobilized PBPC on protocols MAC/G/PB or CY/G/PB had earlier ANC, platelet, and RBC engraftment than patients receiving mobilized $\mathrm{BM}$ progenitors (protocol CY/GM/BM) (Table 2). Further, we observed a strong correlation between time to ANC and platelet engraftment and the number of CFC and LTC-IC infused (Table 3). Although the number of CFC and LTC-IC present in mobilized BM grafts (CY/GM/BM) was lower than mobilized PB grafts, this did not reach statistical significance.

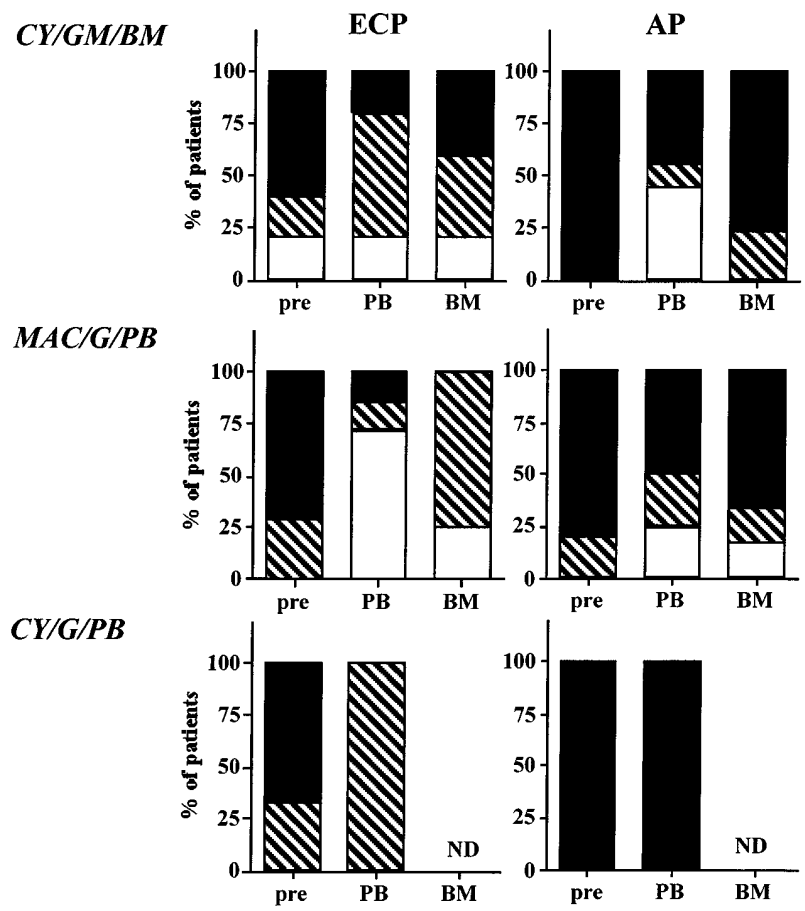

Fig 2. Effect of priming on cytogenetics in BM and PB. Marrow was obtained before priming and PB and BM were obtained after priming on protocols CY/GM/BM, MAC/G/PB, and CY/G/PB from all ECP and AP CML patients. Marrow and PB cells were evaluated by metaphase analysis to detect the number of Ph-positive metaphases. On average, 20 metaphases from steady-state marrow, mobilized marrow, or PB collections were analyzed. For PB collections, the average percent of $\mathbf{P h}$-positive metaphases in all collections was entered in the figure. Results are depicted for all samples that were analyzed and divided as follows: ( $\square$ ), major cytogenetic response, $0 \%$

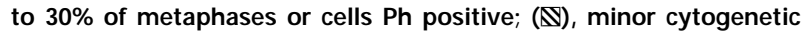
response, $\mathbf{3 0} \%$ to $\mathbf{9 0} \%$ of metaphases or cells $\mathrm{Ph}$ positive; (E), no response, $\mathbf{9 0 \%}$ to $\mathbf{1 0 0 \%}$ of metaphases or cells $\mathrm{Ph}$ positive. 

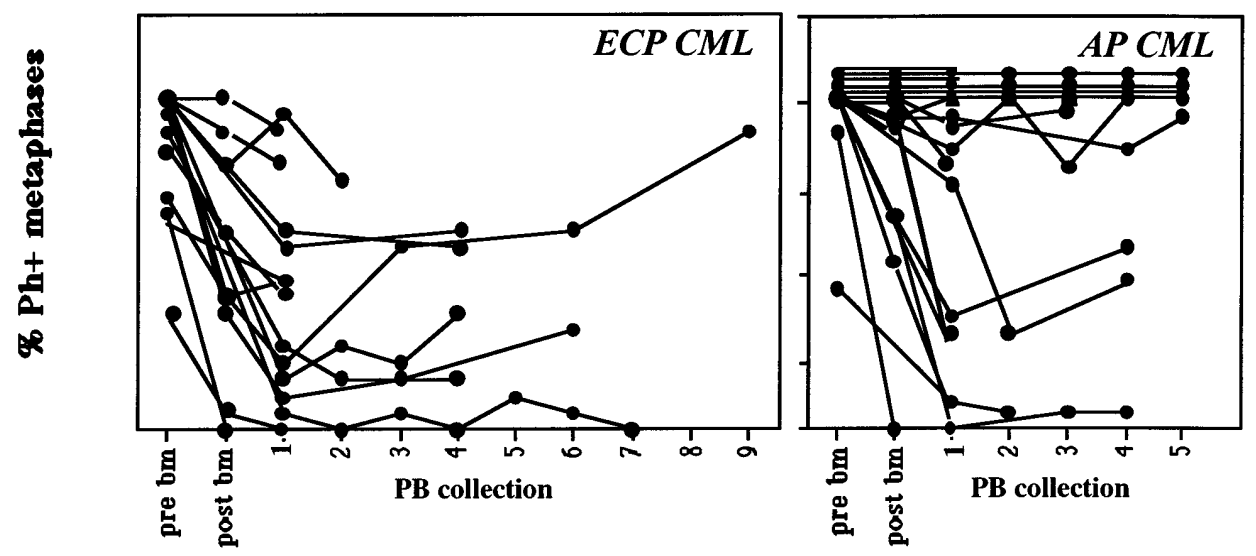

Fig 3. Contamination of sequential PB collections with Ph-positive cells remains relatively constant. Marrow was obtained before priming and PB or BM were obtained after priming on protocols CY/GM/BM, MAC/G/PB, and CY/G/PB from patients with ECP or AP CML. On average, 20 metaphases from steady-state marrow, mobilized marrow, or PB collections were analyzed. Cytogenetic status of all collections are shown separately. In general, cytogenetic responses did not change significantly between the first and last PB collections. Marrow and PB cells were evaluated by metaphase analysis and/or FISH to detect the number of Ph-positive metaphases.

Effect of Graft Composition on Cytogenetics After Transplantation

Five $(33 \%)$ patients on protocol CY/GM/BM obtained a major cytogenetic response ( $>70 \%$ metaphases $\mathrm{Ph}$ negative) 3 weeks after transplantation, four $(27 \%)$ obtained a minor cytogenetic response $(>10 \%$ to $<70 \%$ metaphases $\mathrm{Ph}$ negative), and six (40\%) had $100 \% \mathrm{Ph}$-positive metaphases in recovering BM (Fig 4). All but one patient had reoccurrence of $100 \% \mathrm{Ph}$-positive metaphases in the $\mathrm{BM}$ during the 12 to 24 months after transplantation, and all but one surviving patient are $100 \% \mathrm{Ph}$ positive at 2 years. Six (43\%) patients on protocol MAC/G/BM obtained a major cytogenetic response, four (29\%) obtained a minor cytogenetic response, and four (29\%) recovered 100\% Ph-positive BM (Fig 4). Similar results were observed for patients on CY/G/PB. Two (33\%) patients obtained a major cytogenetic remission, one $(17 \%)$ obtained a minor cytogenetic response, and three $(50 \%)$ continued to be $100 \% \mathrm{Ph}$ positive after transplantation.

We compared the cytogenetic response of patients transplanted in ECP versus more advanced CML. Because no significant differences were seen between patients enrolled in the three sequential protocols, we evaluated all patients combined. Sixty-seven percent (major cytogenetic response), 33\% (minor cytogenetic response), and $0 \%$ (no cytogenetic response) of ECP patients; $29 \%, 29 \%$, and $57 \%$ of LCP CML patients; and $11 \%, 11 \%$, and $78 \%$ of AP patients achieved a major, minor, or no cytogenetic response, respectively. We observed a high correlation between the $\mathrm{Ph}$ status of the inoculum and the $\mathrm{Ph}$ status of the regenerating $\mathrm{BM}$ at 21 days $\left(r^{2}=.71 ; P<.0001\right)$ (Fig 5). This correlation was no longer present at 3 months $\left(r^{2}=.37\right)$, or later after transplantation. For instance, in five of five patients who received a completely or nearly completely $\mathrm{Ph}$-negative graft, a major/complete cytogenetic response was obtained 3 weeks after transplantation. However, BM cytogenetics in four of five patients 6 to 12 months after transplantation were $90 \%$ to $100 \% \mathrm{Ph}$ positive (Fig 6).

Twelve patients have developed cytogenetic evolution since transplantation (21 to 720 days after transplantation), and eight patients have proceeded to blast crisis. Somewhat surprisingly, of the eight patients that died in blast crisis, three were transplanted in ECP. Two of the three patients received a graft that was less than $30 \% \mathrm{Ph}$ positive but developed clonal evolution within 6 months after transplantation leading to blast crisis at days 222 and 777, respectively. One LCP patient in whom the infused graft contained $60 \%$ Ph-positive metaphases developed blast crisis CML at 3 weeks after transplantation. Examination of over 100 metaphases did not show presence of the blast crisis clone in this patient's graft.

\section{Effect of Mobilization on Absolute Number and Clonal Origin of CD $34^{+} H L A-D R^{-}$Cells}

We examined the number and $\mathrm{BCR} / \mathrm{ABL}$ status of CD $34{ }^{+}$HLA-DR $^{-}$cells in steady-state and mobilized PB and $\mathrm{BM}$ obtained from these patients. To compare the number of CD $34^{+} \mathrm{HLA}_{-} \mathrm{DR}^{-}$cells in $\mathrm{PB}$ or BM, we extrapolated the actual number of cells recovered by fluorescence-activated cell sorting (FACS) from the BM sample to $2.5 \mathrm{~L}$ of $\mathrm{BM}$ and extrapolated the number of cells recovered by FACS from each PBPC collection by combining the number of cells/collection in all PBPC ( 2 to 8 collections) collections. Because no significant

Table 3. Correlation Between Cell Dose and Time to Engraftment

\begin{tabular}{|c|c|c|c|c|c|c|}
\hline & $\begin{array}{l}\text { Time to WBC } \\
\text { Engraftment }\end{array}$ & $P$ & $\begin{array}{l}\text { Time to RBC } \\
\text { Engraftment }\end{array}$ & $P$ & $\begin{array}{l}\text { Time to PIt } \\
\text { Engraftment }\end{array}$ & $P$ \\
\hline CD34+ cells/kg & $1.01(1-1.03)^{*}$ & .12 & $1.01(0.99-1.02)$ & .53 & $1.01(1-1.31)$ & .11 \\
\hline $\mathrm{CFC} / \mathrm{kg}$ & 1.16 (1.05-1.28) & $<.01$ & 1.16 (1.02-1.32) & .03 & $1.17(1.04-1.32)$ & $<.01$ \\
\hline LTC-IC/kg & $1.57(1.05-2.36)$ & .03 & $1.73(1.0-3.09)$ & .07 & $1.85(1.11-310)$ & .02 \\
\hline
\end{tabular}

*Cox regression analysis relative risk and 95\% Cls. 

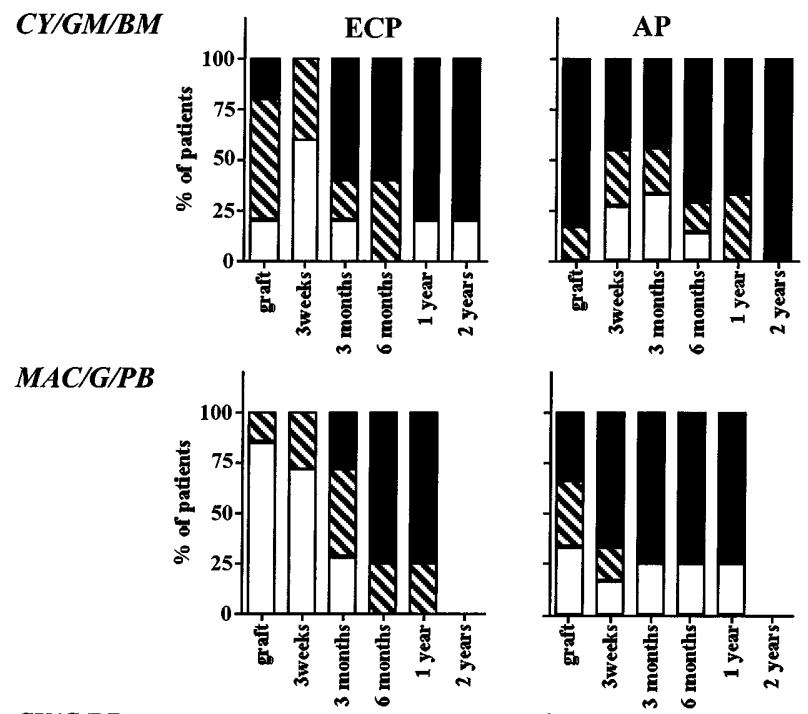

CY/G/PB
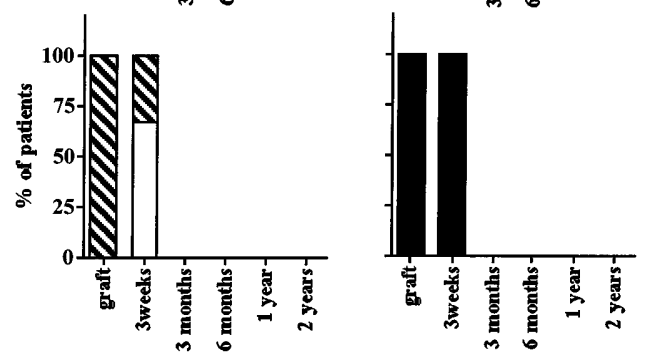

Time after transplant

Fig 4. Cytogenetic outcome after transplantation. The BM or PB inoculum used for grafting as well as BM obtained 3 weeks, 3 months, 6 months, 12 months, and 24 months from all evaluable patients on protocols $\mathrm{CY} / \mathrm{GM} / \mathrm{BM}, \mathrm{MAC} / \mathrm{G} / \mathrm{PB}$, and $\mathrm{CY} / \mathrm{G} / \mathrm{PB}$ were evaluated by metaphase analysis to detect the number of $\mathrm{Ph}$-positive metaphases. On average, 20 metaphases from marrow obtained after transplantation were analyzed. Patients with ECP CML and AP CML were analyzed separately. Results are depicted for all samples that were analyzed and divided as follows: ( $\square$ ), major cytogenetic response, $0 \%$

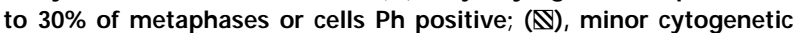
response, $30 \%$ to $\mathbf{9 0} \%$ of metaphases or cells Ph positive; ( $\square$ ), no response, $90 \%$ to $100 \%$ of metaphases or cells Ph positive.

differences were observed between protocols, data were pooled for ECP patients and patients with more advanced disease.

In ECP CML patients, $2 \pm 0.8 \times 10^{6}\left(0.02\right.$ to $\left.9.7 \times 10^{6}\right)$ CD34 ${ }^{+} \mathrm{HLA}_{-} \mathrm{DR}^{-}$cells were present in $2.5 \mathrm{~L}$ steady-state BM. A similar number of $\mathrm{CD} 34^{+} \mathrm{HLA}-\mathrm{DR}^{-}$cells was present in all PBPC collections combined $\left(2.85 \pm 0.7 \times 10^{6}[0.08\right.$ to $7.6 \times$ $\left.\left.10^{6}\right][P=.59]\right)$. However, significantly fewer $(0.16 \pm 0.06 \times$ $10^{6}\left[0.01\right.$ to $\left.\left.0.49 \times 10^{6}\right]\right) \mathrm{CD}^{2} 4^{+} \mathrm{HLA}^{-\mathrm{DR}^{-}}$cells were present per 2.5L BM after mobilization (compared with mobilized PBPC) $(P=.04)$.

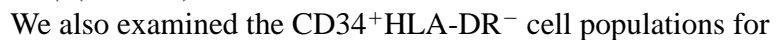
contamination with BCR/ABL mRNA-positive cells. We and others have previously shown that results from fluorescent in situ hybridization (FISH) and nested RT-PCR for the BCR/ABL gene rearrangement in $\mathrm{CD} 34^{+}$subpopulations provide similar results. ${ }^{22,41}$ In previous studies we also evaluated the clonal

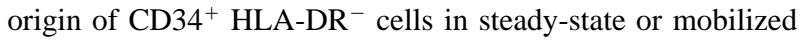
progenitor populations of female CML patients (X-chromo- some inactivation by HUMARA assay). We showed that RT-PCR-negative populations are polyclonal, giving further credence to the notion that these cells are highly enriched in polyclonal, benign, Ph-negative progenitors. ${ }^{42}$ Steady-state BM $\mathrm{CD} 3{ }^{+}{ }^{\text {HLA-DR }}{ }^{-}$cells from five of seven evaluated ECP patients were RT-PCR negative. CD34 ${ }^{+} \mathrm{HLA}_{-} \mathrm{DR}^{-}$cells in mobilized BM were BCR/ABL mRNA-negative in six of eight patients. For mobilized PBPC collections, presence of BCR/ ABL mRNA was analyzed in all available samples. In five patients, collections obtained on different days were examined. In four patients, CD34 ${ }^{+} \mathrm{HLA}^{-\mathrm{DR}^{-}}$cells present in all analyzed PBPC collected were BCR/ABL mRNA negative, whereas in a fifth patient one of the two collections that was analyzed contained BCR/ABL-positive CD $34^{+} \mathrm{HLA}^{-\mathrm{DR}^{-}}$cells.

The minimum dose of $\mathrm{CD} 34^{+} \mathrm{HLA}-\mathrm{DR}^{-}$cells required for timely engraftment in humans is not known. We have previously postulated that a CD $34^{+} \mathrm{HLA}_{-}-\mathrm{DR}^{-}$cells dose of $4 \times$ $10^{5} / \mathrm{kg}$ may be sufficient for prompt engraftment. This was based on the relative proportion of $\mathrm{CD} 34^{+} \mathrm{HLA}-\mathrm{DR}^{-}$cells present within the $\mathrm{CD} 34^{+}$population $(<10 \%)$ and the minimum dose of $2 \times 10^{6} \mathrm{CD} 34^{+}$cells $/ \mathrm{kg}$ required to establish engraftment. ${ }^{43}$ Therefore, a dose of $4 \times 10^{5} \mathrm{CD} 34^{+} \mathrm{HLA}^{-D R}{ }^{-}$ cells $/ \mathrm{kg}$, which is two to four times higher than the calculated minimal "safe" dose, should suffice for timely engraftment. Three of 13 ECP patients had sufficient CD34 ${ }^{+}$HLA-DR $^{-}$ cells/2.5 L steady-state BM, and in 3 of 3 patients these cells were BCR/ABL mRNA negative (Fig 7). None of the BM obtained after mobilization contained $>4 \times 10^{5} \mathrm{CD} 34^{+} \mathrm{HLA}-$ $\mathrm{DR}^{-}$cells $/ \mathrm{kg}$. Mobilized PBPC collections from 5 of 13 patients had $>4 \times 10^{5} \mathrm{CD}^{+} 4^{+} \mathrm{HLA}^{-D_{2}}{ }^{-}$cells that were BCR/ABL mRNA negative in 4 of 5 patients. Recent autografting studies in multiple myeloma suggest that a minimum dose of $6 \times 10^{5} \mathrm{CD} 34^{+} \mathrm{Lin}^{-} \mathrm{Thy}_{1}{ }^{\text {low }}$ cells $/ \mathrm{kg}$ may be required for timely engraftment. ${ }^{44}$ Using these criteria, steady-state BM of 3 patients and mobilized PB from 3 patients would contain
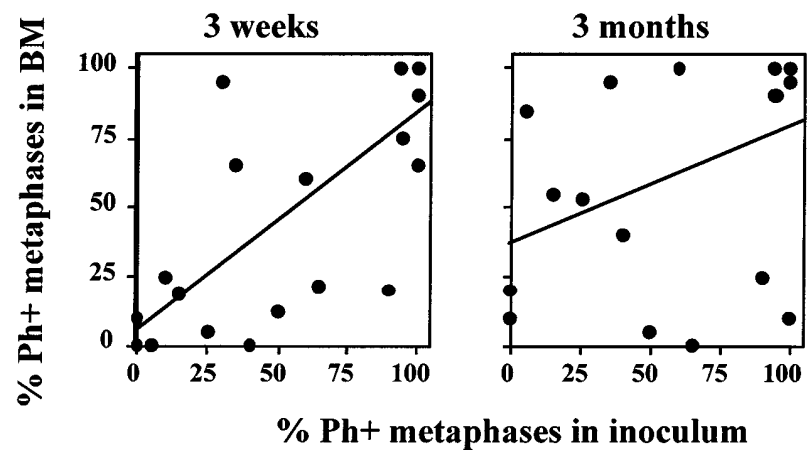

Fig 5. Degree of Ph-positive cell contamination of the graft predicts cytogenetic response 3 weeks, but not 3 months, after transplantation. Marrow or PB inoculum and BM obtained 3 weeks and 3 months after autografting was examined by metaphase analysis or FISH to determine the number of Ph-positive cells present. The number of Ph-positive cells found in the inoculum was then correlated with the number of Ph-positive cells present in BM after transplantation. A good correlation is observed between the cytogenetic response in the inoculum and at 3 weeks after transplantation. However, no correlation is observed between the cytogenetic response in the inoculum and 3 months after transplantation. 

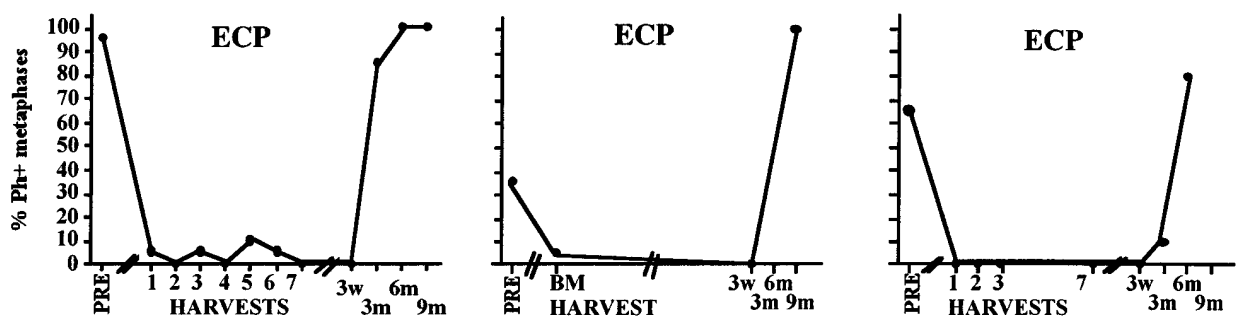

Fig 6. Cytogenetic relapse observed early after transplantation even in patients in whom the inoculum was completely or almost completely $\mathbf{P h}$ negative. Depicted is the posttransplantation cytogenetic analysis of the BM of five individual patients who received a $\mathbf{P h - n e g a t i v e ~ i n - ~}$ oculum.
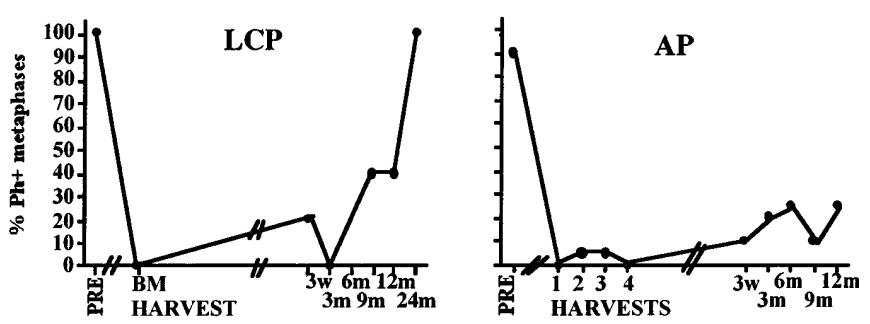

sufficient BCR/ABL-negative $\mathrm{CD} 34{ }^{+} \mathrm{HLA}^{-\mathrm{DR}^{-}}$cells for transplant.

In contrast to ECP CML, in patients with AP disease, the number of $\mathrm{CD} 34^{+} \mathrm{HLA}-\mathrm{DR}^{-}$cells was highly variable but did not change markedly when examined in steady-state BM, in $\mathrm{BM}$ obtained at hematopoietic recovery after mobilization, and in the combined PB collections. As we have previously shown, CD34 ${ }^{+} \mathrm{HLA}_{-} \mathrm{DR}^{-}$cells present in steady-state BM from 8 of 10 AP CML patients contained BCR/ABL mRNA-positive cells. This did not change significantly after mobilization.
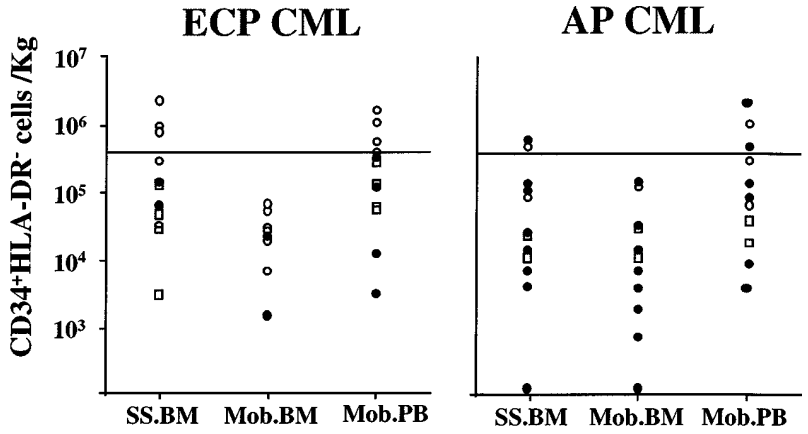

Fig 7. Effect of priming chemotherapy on the number and clonal origin of CD34+HLA-DR- cells in marrow and blood. Marrow was obtained before and BM and PB were obtained after priming chemotherapy. CD34+HLA-DR- cells were selected using sequential FicollHypaque separation, column enrichment, and FACS selection. To calculate the number of $\mathrm{CD}^{+} 4^{+} \mathrm{HLA}^{-D R^{-}}$cells that would be available for transplantation the following calculations were made: For marrow, the number of CD34+ $\mathrm{HLA}^{-D R^{-}}$cells present per $10^{6} \mathrm{BM}$ cells was multiplied by the calculated number of cells present in a hypothetical marrow harvest of $2.5 \mathrm{~L}$. For PBPC collections, the number of CD34+HLA-DR- cells in each PB collection was determined by multiplying the number of CD34+HLA-DR- cells present in $10^{6} \mathrm{~PB}$ cells and the total number of cells per collection. When more than one collection was obtained, the number of CD34+ ${ }^{+}$HA-DR $^{-}$cells in each collection was combined to calculate the total number of CD34+HLADR- cells available for transplantation. The number of CD34+ ${ }^{+}{ }^{-}$A $^{-D R^{-}}$ cells available was then divided by the weight of the patient to determine CD34 ${ }^{+}$HLA-DR $^{-}$cells/ $/$kg. $^{(}()$), BCR-ABL negative; (๑), BCRABL positive; ( $\square$ ), no PCR.
Interestingly, the ability to identify BCR/ABL mRNAnegative $\mathrm{CD}_{3}{ }^{+} \mathrm{HLA}-\mathrm{DR}^{-}$cells in the mobilized $\mathrm{BM}$ or $\mathrm{PB}$ products correlated significantly with the cytogenetic status at multiple timepoints after transplantation. A significant correlation was observed between presence of BCR/ABL mRNAnegative $\mathrm{CD}^{+} 4^{+} \mathrm{HLA}-\mathrm{DR}^{-}$cells and $\mathrm{Ph}$ negativity at 3 weeks $\left(\mathrm{N}=17, r^{2}=.72, P=.001\right), 3$ months $\left(\mathrm{N}=17, r^{2}=.65, P=\right.$ $.004), 6$ months $\left(\mathrm{N}=12, r^{2}=.55, P=.049\right)$, and 9 months $\left(\mathrm{N}=10, r^{2}=.58, P=.034\right)$ after transplantation.

\section{DISCUSSION}

The goals of the present study were (1) to compare the effect of intermediate or high-dose chemotherapy priming on the cytogenetic response in mobilized BM or PB progenitors, (2) to determine the incidence of cytogenetic remissions and relapse after mobilized progenitor transplantation in ECP and more AP CML, and (3) to determine the effect of in vivo priming on the ability to select $\mathrm{Ph}$-negative $\mathrm{CD} 34^{+} \mathrm{HLA}^{-\mathrm{DR}^{-}}$cells from mobilized BM or PB sufficient for transplantation.

We show that cytogenetic responses observed in $\mathrm{PB}$ or BM after priming with either cyclophosphamide alone or a more intensive regimen of cyclophosphamide, mitoxantrone, and cytosine arabinoside were equivalent. The degree of $\mathrm{Ph}$ negativity in PB collections collected after CY/GM, MAC/G, or CY/G mobilization was similar. Likewise, similar cytogenetic responses were observed in BM or PB after either mobilization regimen. The strategy to mobilize $\mathrm{Ph}$-negative progenitors using intensive chemotherapy was first described by the Genoa group. ${ }^{19}$ They reported that almost exclusively Ph-negative cells, and in some cases BCR/ABL mRNA-negative cells, can be mobilized in the blood in greater than $50 \%$ of patients who underwent mobilizing chemotherapy at diagnosis. ${ }^{19,29,30}$ Outcomes after transplant with Ph-negative grafts collected early after diagnosis were favorable: reestablishment of Ph-negative hematopoiesis in $50 \%$ of patients and persistent $\mathrm{Ph}$-negative hematopoiesis for at least 12 months in greater than $50 \%$ of patients. Later reports from the same group have shown that results for patients who undergo mobilization at later time points ( $>1$ year from diagnosis) or after treatment with IFN- $\alpha$ 
are less favorable: partial or no cytogenetic responses are observed in the mobilized graft; transplantation with such a graft rarely leads to a complete cytogenetic response even immediately after transplantation. ${ }^{30}$ Since then, several other groups have used chemotherapy to induce Ph-negative hematopoiesis before blood or BM harvest. ${ }^{31-35,41}$ Most investigators have noted a considerable variability in the results obtained. Although chemotherapy mobilization can induce complete or partial cytogenetic responses in a subset of patients, results are in general not as predictable or as compelling as those originally described.

We found that mobilization of Ph-negative cells in the blood of patients with CML is possible. However, we rarely observed a complete Ph-negative state of the graft and in no patient was the graft BCR/ABL mRNA negative. Differences between our results and those published by the Genoa group may be due to differences in the chemotherapy regimens used. Instead of ICE (ifosfamide, cytarabine, etoposide) or mini-ICE, we used cyclophosphamide alone or in combination with mitoxantrone and cytosine arabinoside. The median duration of neutropenia of 15 to 18 days after mobilization with either of the priming regimens used in our studies is similar to that reported for mobilization with the mini-ICE protocol, ${ }^{30,33-35}$ although shorter than seen after priming with ICE. ${ }^{19,29}$ This suggests that regimens used in our studies are of similar dose intensity as the mini-ICE regimen and that differences in dose intensity between mobilization regimens used in different studies may not significantly impact on the $\mathrm{Ph}$ status of the mobilized graft. We cannot exclude that the shorter duration of chemotherapy administration in our patients ( 5 to 7 days for ICE and mini-ICE $v 2$ days for cyclophosphamide, ARA-C, and mitoxantrone used in our study) may negatively impact on the type of cells that are mobilized in the blood when the marrow recuperates. An alternative explanation is that differences reported by different investigators may be due to patient selection. The median time from diagnosis for ECP patients enrolled in our studies was 8 months (range, 7 to 11 months). The best results have been reported for mobilizations performed immediately after diagnosis. As the benign hematopoietic clone decreases with time, ${ }^{22}$ it is possible that the lower proportion of $\mathrm{Ph}$-negative cells mobilized in the $\mathrm{PB}$, observed in our studies and reported by other investigators for patients with ECP CML, may in part be due to the fact that the normal stem cell pool has decreased considerably even 8 months after diagnosis.

After transplantation with mobilized progenitors obtained using the three different mobilization regimens, no significant differences were observed in cytogenetic response. This is consistent with the observation that the three mobilization regimens induced similar degrees of $\mathrm{Ph}$ negativity in the graft and that the Ph status 3 weeks after transplantation is highly correlated with the degree of $\mathrm{Ph}$ negativity in the graft. Of interest, cytogenetic status at 3 or more months after transplantation did not correlate with the degree of Ph negativity in the mobilized graft. However, cytogenetic response at 3 to 9 months was highly correlated with the disease stage at time. Thus, as has been observed for other autograft approaches in CML, outcome after mobilized PB or BM transplants may depend more on the disease stage at the time of transplantation than the type of mobilization regimen used or source of progenitor used (BM or PB). ${ }^{20,21,26-35}$ Irrespective of the cytogenetic response in the graft or at 3 weeks after transplantation, only two patients on the first two protocols remain in major cytogenetic remission beyond 12 months after transplantation.

Of interest, cytogenetic response at 3 to 9 months was also highly correlated with our ability to identify and select large

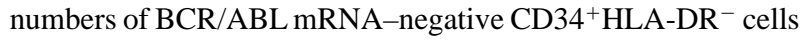
from mobilized $\mathrm{BM}$ or $\mathrm{PB}$. Our studies show that presence of $\mathrm{BCR} / \mathrm{ABL}-$ negative $\mathrm{CD} 34^{+} \mathrm{HLA}_{-} \mathrm{DR}^{-}$cells in the graft predicts cytogenetic remission after transplant significantly better than cytogenetic analysis of the mononuclear cells in the graft. It is possible that the correlation found between BCR/ABL-

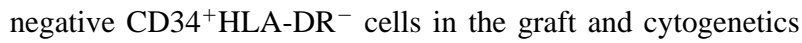
after transplant is a manifestation of disease stage at the time of transplant. Because relapse after autografting may be due to contamination of the graft, as shown by gene marking studies, ${ }^{45}$ and due to persistent disease in the host, as exemplified by syngeneic or T-cell-depleted allografts, ${ }^{13-15}$ cytogenetic relapses observed at 6 months or later after grafting may be the result of Ph-positive stem cells contaminating the graft or may be the result of disease persisting in the host. Relapses occurred significantly later in patients in whom the graft contained a larger population of $\mathrm{BCR} / \mathrm{ABL}-$ negative $\mathrm{CD} 34^{+} \mathrm{HLA}^{-\mathrm{DR}^{-}}$ cells. We hypothesize that decreased contamination of the graft contributes to the delay in relapse observed. An alternative or complementary explanation may be that disease in this group of patients is more chemotherapy and radiation therapy responsive, resulting in a significantly greater depletion of the malignant population in the host with the mobilization and the pretransplant cytoreductive therapy. Stem cell marking studies at our institution in patients with $\mathrm{CP}$ CML are currently underway to discriminate between these possibilities.

Four patients died early after transplantation due to regimen associated toxicity (one graft failure and three infectious/toxic deaths). These four patients were either LCP patients or patients with AP disease: time from diagnosis was 3 to 6 years and two patients were in AP disease. As has been shown for allogeneic transplant regimens, time from diagnosis and presence of accelerated features are associated with increased toxic deaths. ${ }^{13-15}$ Of note, $27 \%$ of patients developed progressive disease 1 month to 3 years after transplantation. Sixteen percent of patients progressed to blast crisis CML. Early progression to blast crisis was independent of patient age, peripheral WBC count, platelet count, spleen size at the time of transplantation, or previous therapy. Progression to blast crisis was observed more often in patients with long-standing disease (LCP) or with accelerated features. For the three patients transplanted in presumed ECP CML who progressed to blast crisis within 1 to 3 years after transplant, none of the characteristics listed above predicted the transformation. In one late CP CML patient who progressed to blast crisis 3 weeks after transplantation, the clonal abnormalities observed at the time of blast crisis could not be detected in the graft inoculum. Progression to blast crisis was also independent of the type of mobilizing chemotherapy used. It is possible that the mobilization and preparative regimen selectively eliminates the $\mathrm{CP}$ clone but not subclones with additional genetic abnormalities, which may be undetectable before priming. As has been described for autologous transplantations in lymphoproliferative disorders, ${ }^{46-48}$ repeated 
administration of chemotherapy may induce additional clonal abnormalities in CML. In CML, the known increased resistance to apoptosis conferred by the BCR/ABL oncoprotein ${ }^{49,50}$ may enhance the tendency to acquire additional genetic abnormalities leading to rapid clonal expansion and premature blast crisis disease.

We found that use of mobilized PB progenitors rather than mobilized BM progenitors resulted in earlier engraftment. A strong correlation was observed between the number of CFC and LTC-IC infused and the time to ANC, platelet, and RBC recovery. Although differences in CFC and LTC-IC content between mobilized $\mathrm{BM}$ progenitors (protocol $\mathrm{CY} / \mathrm{GM} / \mathrm{BM}$ ) and mobilized PB collections (protocols $\mathrm{CY} / \mathrm{G} / \mathrm{PB}$ and $\mathrm{MAC} / \mathrm{G} / \mathrm{PB}$ ) did not reach statistical significance, there was a trend to higher progenitor content in the mobilized PB grafts. Thus, slower engraftment in protocol CY/GM/BM may be caused by the lower progenitor dose infused. Alternatively, differences in cytokines used for mobilization and posttransplant support or intrinsic differences between mobilized BM and PB progenitors may in part be responsible for the differences in hematopoietic recovery observed between the protocols..$^{51-53}$

The last objective of the study was to evaluate if in vivo mobilization would increase the number of patients in whom ex vivo selection of a BCR/ABL mRNA-negative population of CD $34^{+}$HLA-DR $^{-}$cells is feasible. In ECP CML, the number of $\mathrm{CD}^{+}{ }^{+} \mathrm{HLA}^{-\mathrm{DR}^{-}}{ }^{-}$cells in mobilized $\mathrm{BM}$ was lower than in steady-state BM. However, more CD $34{ }^{+} \mathrm{HLA}_{-} \mathrm{DR}^{-}$cells could be selected from the combined mobilized PB collections than from steady-state BM. Further, irrespective of mobilization, CD34 ${ }^{+} \mathrm{HLA}_{-} \mathrm{DR}^{-}$cells were BCR/ABL mRNA negative and polyclonal $^{42}$ in the majority of ECP CML patients. In contrast, the number and clonal origin of CD34 ${ }^{+} \mathrm{HLA}_{-} \mathrm{DR}^{-}$cells was not significantly affected by the priming chemotherapy in patients with more advanced CML. The presence of large numbers of BCR/ABL mRNA-negative CD $34^{+} \mathrm{HLA}^{-} \mathrm{DR}^{-}$cells in the graft was associated with superior cytogenetic response after transplantation with mobilized grafts. Therefore, we speculate that combined approaches in which the $\mathrm{CD} 34^{+} \mathrm{HLA}-\mathrm{DR}^{-}$cell population is selected from mobilized PB collections may result in longer lasting and more significant cytogenetic responses after transplantation.

In conclusion, we describe results of autografting using mobilized $\mathrm{PB}$ or $\mathrm{BM}$ progenitors in CML. These studies indicate that neither the intensity of the mobilizing regimen nor the source of stem cells significantly affects the cytogenetic remissions obtained immediately after mobilization or after transplantation. However, cytogenetic responses in the mobilized product or after transplantation are significantly correlated with the number of benign primitive progenitors still present, which is significantly higher in ECP than in later stages of the disease. We show a correlation between the percent of $\mathrm{Ph}-$ negative committed progenitors present in the inoculum and the percent of $\mathrm{Ph}$-negative progenitors present 3 weeks after transplantation. However, this effect is short lived, indicating that either more primitive progenitors continue to be $\mathrm{Ph}$ positive and/or that disease persisting in the host after the myeloablative therapy contributes to cytogenetic relapse. Finally, all patients received IFN- $\alpha$ as maintenance therapy after transplantation. In all but 2 patients, IFN did not prevent resurgence of the
Ph-positive clone. Additional posttransplantation therapies, such as interleukin-2 with antileukemia lymphoid cell populations ${ }^{54}$ or continued administration of chemotherapy after transplantion of a graft modified by a drug resistance gene, ${ }^{55}$ will need to be tested to prevent the inexorable progression to cytogenetic relapse observed after auto-transplantation for CML.

\section{REFERENCES}

1. Fialkow PJ, Jacobson RJ, Papayannopoulou TH: Chronic myelocytic leukemia: Clonal origin in a stem cell common to the granulocyte, erythrocyte, platelet and monocyte/ macrophage. Am J Med 63:125, 1977

2. Rowley JD: A new consistent chromosome abnormality in chronic myelogenous leukemia. Nature 243:209, 1973

3. Bartram CR, de Klein A, Hagemeijer A, van Agthoven T, Geurts van Kessel A, Bootsma D, Grosveld G, Ferguson-Smith MA, Davies T, Stone M: Translocation of the c-abl oncogene adjacent to a translocation break point in chronic myelocytic leukemia. Nature 306:277, 1983

4. Daley GQ, Van Etten RA, Baltimore D: Induction of chronic myelogenous leukemia in mice by the P210 $210^{\mathrm{BCR}-\mathrm{ABL}}$ gene of the Philadelphia chromosome. Science 247:824, 1990

5. Pendergast AM, Gishizky ML, Havlik MH, Witte ON: SH1 domain autophosphorylation of $\mathrm{p} 210 \mathrm{BCR}-\mathrm{ABL}$ is required for transformation but not growth factor independence. Mol Cell Biol 13:1728, 1993

6. McWhirter JR, Wang JY: An actin-binding function contributes to transformation by the BCR-ABL oncoprotein in Philadelphia chromosome positive human leukemias. EMBO J 12:1533,1993

7. Kantarjian HM, Smith TL, McCredie KB, McCredie KB, Keating MJ, Walters RS, Talpaz M, Hester JP, Bligham G, Gehan E, Freireich EJ: Chronic myelogenous leukemia: A multivariate analysis of the associations of patient characteristics and therapy with survival. Blood 66:1326, 1985

8. Wetzler M, Kantarjian H, Kurzrock R, Talpaz M: Interferon-alpha therapy for chronic myelogenous leukemia. Am J Med 9:402, 1995

9. Allan NC, Richards SM, Shepherd PC: UK Medical Research Council randomised, multicentre trial of interferon-alpha for chronic myeloid leukaemia: Improved survival irrespective of cytogenetic response. The UK Medical Research Council's Working Parties for Therapeutic Trials in Adult Leukaemia. Lancet 345:1392, 1995

10. Anonymous. Chronic myeloid leukemia, BCR/ABL transcript, response to alpha-interferon and survival. The Italian Cooperative Study Group on Chronic Myeloid Leukemia. Leukemia 9:1648, 1995

11. Hehlmann R, Heimpel H, Hasford J, Kolb HJ, Pralle H, Hossfeld DK, Queisser W, Loffler H, Hochhaus A, Heinze B: Randomized comparison of interferon-alpha with busulfan and hydroxyurea in chronic myelogenous leukemia. The German CML Study Group. Blood 84:4064, 1994

12. Guilhot F, Chastang C, Michallet M, Guerci A, Harousseau JL, Maloisel F, Bouabdallah R, Guyotat D, Cheron N, Nicolini F, Abgrall $\mathrm{JF}$, Tanzer J: Interferon alfa-2b combined with cytarabine versus interferon alone in chronic myelogenous leukemia. French Chronic Myeloid Leukemia Study Group. N Engl J Med 337:223, 1997

13. McGlave P: Bone marrow transplants in chronic myelogenous leukemia: An overview of determinants of survival. Semin Hematol 27:23, 1990

14. McGlave P: Unrelated donor and autologous marrow transplant therapy of chronic myelogenous leukemia. Leukemia 7:1082, 1993

15. Enright H, Davies SM, DeFor T, Shu X, Weisdorf D, Miller W, Ramsay NKC, Arthur D, Verfaillie C, Miller J, Kersey J, McGlave P: Relapse after non-T-cell-depleted allogeneic bone marrow transplantation for chronic myelogenous leukemia: Early transplantation, use of an unrelated donor, and chronic graft-versus-host disease are protective. Blood 88:714, 1996 
16. Takahira H, Ideguchi H, Hirata J, Yamamoto M, Ideguchi $\mathrm{H}$, Nishimura J, Nawata H: Appearance of chromosomally normal hemopoiesis during busulfan-induced remission in a case of $\mathrm{Ph} 1$ positive chronic myelogenous leukemia. Rinsho Ketsueki 30:251, 1989

17. Goto T, Nishikori M, Arlin A, Gee T, Kempin S, Burchenal JA, Wisniewski D, Lambek C, Little C, Jhanwar S, Chaganti R, Clarkson B: Growth characteristics of leukemic and normal hematopoietic cells in $\mathrm{Ph}$ ' + chronic myelogenous leukemia and effects of intensive treatment. Blood 59:793, 1982

18. Kantarjian HM, Talpaz M, Hester J, Feldman E, Korbling M, Liang J, Rios MB, Smith TL, Calvert L, Deisseroth AB: Collection of peripheral-blood diploid cells from chronic myelogenous leukemia patients early in the recovery phase from myelosuppression induced by intensive-dose chemotherapy. J Clin Oncol 13:553, 1995

19. Carella AM, Podesta M, Frassoni F, Pungolino E, Pollicardo N, Raffo MR, Ferrero R, Benvenuto F, Figari O, Giordano D: Selective overshoot of Ph-negative blood hemopoietic cells after intensive idarubicin-containing regimen and their repopulating capacity after reinfusion. Stem Cells 11:67, 1993 (suppl 3)

20. Coulombel L, Kalousek DK, Eaves CJ, Gupta CM, Eaves AC: Long-term marrow culture reveals chromosomally normal hematopoietic progenitor cells in patients with Philadelphia chromosome-positive chronic myelogenous leukemia. N Engl J Med 308:1493, 1983

21. Barnett M, Eaves C, Phillipps G, Gascoyne R, Hogge D, Horsman D, Humphries R, Klingemann H, Lansdorp P, Nantel S, Reece D, Shepherd J, Spinelli J, Sutherland H, Eaves A: Autografting with cultured marrow in chronic myeloid leukemia: Results of a pilot study. Blood 84:724, 1994

22. Verfaillie CM, Bhatia R, Miller W, Mortari F, Roy V, Stiegelbauer K, Dewald G, Miller JS, McGlave PB: Benign primitive progenitors can be selected on the basis of the CD34+/HLA-DRphenotype in early chronic phase but not advanced phase CML. Blood 87: 4770, 1996

23. Verfaillie CM, Miller WJ, Boylan K, McGlave PB: Selection of benign primitive hematopoietic progenitors in chronic myelogenous leukemia on the basis of HLA-DR antigen expression. Blood 79:1003, 1992

24. Kirk J, Reems JA, Roecklein BA, Van Devanter DR, Bryant EM, Radich J, Edmands S, Lee A, Torok-Storb B: Benign marrow progenitors are enriched in the CD34+/HLA-DRlo population but not in the CD34+/CD38lo population in chronic myeloid leukemia: An analysis using interphase fluorescence in situ hybridization. Blood 86:737, 1995

25. Leemhuis T, Leibowitz D, Cox G, Srour EF, Tricot G, Hoffman $\mathrm{R}$ : Identification of BCR/ABL-negative primitive hematopoietic progenitor cells within chronic myeloid leukemia marrow. Blood 81:801, 1993

26. McGlave PB, Arthur D, Miller WJ, Lasky L, Kersey J: Autologous transplantation for CML using marrow treated ex vivo with recombinant human interferon gamma. Bone Marrow Transplant 6:115, 1990

27. Carlo-Stella C, Mangoni L, Almici C, Caramatti C, Cottafavi L, Dotti G, Rizzoli V: Autologous transplant for chronic myelogenous leukemia using marrow treated ex vivo with mafosfamide. Bone Marrow Transplant 14:425, 1994

28. Gewirtz AM: Treatment of chronic myelogenous leukemia (CML) with c-myb antisense oligodeoxynucleotides. Bone Marrow Transplant 14:S57, 1994 (suppl 3)

29. Carella AM, Podesta M, Grassoni F, Pungolino E, Pollicardo NR, Soracco M: Selective overshoot of Ph-negative blood hemopoietic cells after an intensive idarubicin-containing regimen and their repopulating capacity after reinfusion. J Hematother 3:199, 1994

30. Carella A, Cunningham I, Lerma E, Dejana A, Benvenuto F, Podesta M, Celesti L, Chimirri F, Abate M, Vassallo F, Figari O, Parodi C, Sessarego M, Valbonesi M, Carlier P, Prencipe E, Gatti A, Van Den Berg D, Hoffman R, Frassoni F: Mobilization and transplantation of
Philadelphia-negative peripheral-blood progenitor cells early in chronic myelogenous leukemia. J Clin Oncol 15:1575, 1997

31. Talpaz M, Kantarjian H, Liang J, Calvert L, Hamer J, Tibbits P, Durett A, Claxton D, Giralt S, Khouri I, Przepiorka D, Van Besien K, Andersson B, Mehra R, Gajewski J, Seong D, Hester J, Estey K, Korbling M, Pollicardo N, Berenson R, Heimfeld S, Champlin R, Deisseroth A: Percentage of Philadelphia chromosome ( $\mathrm{Ph}$ )-negative and $\mathrm{Ph}$-positive cells found after autologous transplantation for chronic myelogenous leukemia depends on percentage of diploid cells induced by conventional-dose chemotherapy before collection of autologous cells. Blood 85:3257, 1995

32. Chalmers EA, Franklin IM, Kelsey SM, Newland AC, Clark RE, Sproul AM, Crotty G, McCann SR, Fielding A, Goldstone AH, Hepplestone A, Watson W, Sharp RA, Tansey P: Treatment of chronic myeloid leukaemia in first chronic phase with idarubicin and cytarabine: Mobilization of Philadelphia-negative peripheral blood stem cells. Br J Haematol 96:627, 1997

33. Hughes T, Grigg A, Szer J, Ho J, Ma D, Dale B, Green R, Norman J, Sage R, Herrmann R, Cannell P, Schwarer A, Taylor K, Atkinson K, Arthur C: Mobilization of predominantly Philadelphia chromosome-negative blood progenitors using cyclophosphamide and rHUG-CSF in early chronic-phase chronic myeloid leukemia: Correlation with Sokal prognostic index and haematological control. Br J Haematol 96:635, 1997

34. Simonsson B, Oberg O, Bjoreman M, Bjorkholm M, Carneskog J, Gahrton G, Hast H, Karl H, Lanng-Nielsen J, Lofvenberg E, Malm C, Turesson I, Uden A, Vilen L, Weis-Bjerrum O for the Danish-Swedish CML Group: Intensive treatment in order to minimize the $\mathrm{Ph}$-positive clone in CML. Bone Marrow Transplant 17:63, 1996 (suppl 3)

35. Boque C, Petit J, Sarra J, Cancelas JA, Munoz J, Espanol JI, de la Banda E, Aventin A, Berlanga J, Ferra C, Amill B, Torrico C, Azqueta C, Llucia M, Garcia J, Granena A: Mobilization of peripheral stem cells with intensive chemotherapy (ICE regimen) and G-CSF in chronic myeloid leukemia. Bone Marrow Transplant 18:879, 1996

36. Enright H, Daniels K, Arthur DC, Dusenbery KE, Kersey JH, Kim T, Miller WJ, Ramsay NK, Vercellotti GM, Weisdorf DJ, McGlave PB: Related donor marrow transplant for chronic myeloid leukemia: Patient characteristics predictive of outcome. Bone Marrow Transplant 17:537, 1996

37. Verfaillie C, McGlave P: Leukemia inhibitory factor (LIF)/ human interleukin for DA cells (HILDA) supports the growth of multipotential hematopoietic cells in vitro. Blood 77: 263, 1991

38. Verfaillie C, Blakolmer K, McGlave P: Purified primitive hematopoietic progenitor cells with long-term in vitro repopulating capacity adhere selectively to irradiated bone marrow stroma. J Exp Med 172:509, 1990

39. Dewald GW, Broderick D J, Tom WT, Hagstrom JE, Pierre RV: The efficacy of direct, 24 hour culture and mitotic synchronization methods for cytogenetic analysis of bone marrow in neoplastic disorders. Cancer Genet Cytogenet 18:1, 1984

40. Ely P, Miller W: BCR/ABL mRNA detection following bone marrow transplantation for chronic myelogenous leukemia. Transplantation 52:1023, 1991

41. Hochhaus A, Lin F, Reiter A, Skladny H, Mason PJ, van Rhee F, Shepherd PC, Allan NC, Hehlmann R, Goldman JM, Cross NC: Quantification of residual disease in chronic myelogenous leukemia patients on interferon-alpha therapy by competitive polymerase chain reaction. Blood 87:1549, 1997

42. Delforge M, Boogaerts M, McGlave PB, Verfaillie CM: CD34+HLA-DR- cells in chronic phase CML, but not in more advanced phase CML, are polyclonal. (submitted)

43. Weaver $\mathrm{CH}$, Hazelton $\mathrm{B}$, Birch $\mathrm{R}$, Palmer P, Allen C, Schwartzberg L, West W: An analysis of engraftment kinetics as a function of the CD34 content of peripheral blood progenitor cell 
collections in 692 patients after the administration of myeloablative chemotherapy. Blood 86:3961, 1995

44. Archimbaud E, Philip I, Coiffier B, Michallet M, Salles G, Sebban C, Roubi N, Lopez F, Bessueille L, Mazars P, Gerard C, Hanania S, Ramanathan R, Reding C, Juttner C, Atkinson K, Philip T: Selected autologous peripheral blood CD34+Thy1+Lin- hematopoietic cell transplantation in multiple myeloma: A European study. Blood 90:1754a, 1997 (abstr, suppl 1)

45. Deisseroth AB, Zhifei Z, Claxton D, Hanania EG, Fu S, Ellerson D, Goldberg L, Thomas M, Janicek K, Anderson WF: Genetic marking shows that $\mathrm{Ph}+$ cells present in autologous marrow of chronic myelogenous leukemia (CML) contribute to relapse after autologous bone marrow transplants in CML. Blood 83:3068, 1994

46. Miller JS, Arthur DC, Litz CE, Neglia JP, Miller WJ, Weisdorf DJ: Myelodysplastic syndrome after autologous bone marrow transplantation: An additional late complication of curative cancer therapy. Blood 83:3780, 1994

47. Nademanee A, O'Donnell MR, Snyder DS, Schmidt GM, Parker PM, Stein AS, Smith EP, Molina A, Stepan DE, Somlo G: High-dose chemotherapy with or without total body irradiation followed by autologous bone marrow and/or peripheral blood stem cell transplantation for patients with relapsed and refractory Hodgkin's disease: Results in 85 patients with analysis of prognostic factors. Blood 85:1381, 1996

48. Gale RE, Bunch C, Moir DJ, Patterson KG, Goldstone AH, Linch DC: Demonstration of developing myelodysplasia/acute myeloid leukaemia in haematologically normal patients after high-dose chemotherapy and autologous bone marrow transplantation using $\mathrm{X}$ chromosome inactivation patterns. Br J Haematol 93:53, 1996

49. Bedi A, Barber JP, Bedi GC, el-Deiry WS, Sidransky D, Vala
MS, Akhtar AJ, Hilton J, Jones RJ: BCR-ABL-mediated inhibition of apoptosis with delay of G2/M transition after DNA damage: A mechanism of resistance to multiple anticancer agents. Blood 86:1148, 1995

50. McGahon A, Bissonnette R, Schmitt M, Cotter KM, Green DR, Cotter TG: BCR-ABL maintains resistance of chronic myelogenous leukemia cells to apoptotic cell death. Blood 83: 1179, 1994

51. Weisdorf D, Miller JS, Verfaillie CM, Burns L, Wagner J, Blazar B, Davies S, Miller W, Hannan P, Steinbuch M, Ramsay N, McGlave P: Cytokine primed marrow stem cells versus peripheral blood stem cells for autologous transplantation: A randomized comparison of GM-CSF and G-CSF. Biol Blood Marrow Transplant 3:217, 1997

52. Bolwell BJ, Goormastic M, Yanssens T, Dannley R, Baucco P, Fishleder A: Comparison of G-CSF with GM-CSF for mobilizing peripheral blood progenitor cells and for enhancing marrow recovery after autologous bone marrow transplant. Bone Marrow Transplant 14:913, 1994

53. Prosper F, Stroncek D, Verfaillie CM: Expansion of primitive LTC-IC from G-CSF mobilized peripheral blood progenitor cells (PBPC). Blood 89:3991, 1997

54. Cervantes F, Pierson BA, McGlave PB, Verfaillie CM, Miller JS: Autologous activated natural killer cells suppress primitive chronic myelogenous leukemia progenitors in long-term culture. Blood 87: 2476, 1996

55. Zhao RC, McIvor RS, Griffin JD, Verfaillie CM: Elimination of tumorigenicity of $\mathrm{BCR} / \mathrm{ABL}$ positive cells in vivo by a retroviral vector containing an anti-BCR/ABL antisense sequence and confers methotrexate resistance. Blood 89:4687, 1997 